\section{Low Temperature Tolerance of Zoysiagrasses}

\author{
J.H. Dunn ${ }^{1}$ \\ Department of Horticulture, University of Missouri, Columbia, MO 65211
}

S.S. Bughrara ${ }^{2}$

Department of Agronomy, University of Missouri, Columbia, MO 65211

M.R. Warmund ${ }^{3}$ and B.F. Fresenburg ${ }^{2}$

Department of Horticulture, University of Missouri, Columbia, MO 65211

Additional index words. Zoysia, cold hardiness, winter injury, cultivar, controlled freezing, field survival

Abstract. Rhizomes of zoysiagrass (Zoysia spp.) were subjected to controlled freezing tests in Jan. and Mar. 1993 and 1994 to determine their low-temperature tolerance. In 1994, 'Belair', 'Korean Common', 'Meyer', and 'TGS-W10' rhizomes survived temperatures as low as $-18{ }^{\circ} \mathrm{C}$, while rhizomes of 'Sunburst' survived $-14{ }^{\circ} \mathrm{C}$. 'Cavalier', 'Crowne', 'Palisades', 'Emerald', and 'El Toro' were killed at $-10{ }^{\circ} \mathrm{C}$ or warmer temperatures. Entries surviving exposure to -14 to $-18{ }^{\circ} \mathrm{C}$ in 1994 controlled freezing tests received postwinter survival ratings in the field of 6.7 to $8.7(9=100 \%$ green $)$. Entries killed at higher freezing test temperatures were slower to recover after winter in the field, with ratings of 2.0 to 3.0. Shoot number produced after freezing was a better measurement for assessing low temperature tolerance than was shoot mass. Controlled freezing tests, using regrowth as a measure of hardiness, appear to be useful for identifying low temperature tolerance of zoysiagrasses in the early years of a field study.

'Meyer' zoysiagrass, Zoysia japonica Steud., is a popular choice for warm-season lawn and golf turf in the Midwest transition zone, where cool-season grasses such as Kentucky bluegrass (Poa pratensis L.) often perform poorly in the summer. Occasional low temperature injury is the principal limiting factor for use of warm-season grasses in this zone. However, Beard (1973) stated that zoysiagrass is more tolerant of low temperature injury than are other warm-season grasses. Rogers et al. (1977) found that zoysiagrass cultivars survived lower temperatures than did bermudagrass (Cynodon dactylon L.) cultivars. Nevertheless, potential for low temperature injury has limited extensive use of zoysiagrass in the Midwest to the cultivar 'Meyer'. The development of a larger pool of low temperature-tolerant zoysiagrass cultivars remains an important breeding objective.

The traditional approach to selection for low-temperature tolerance is to evaluate field plots in the spring following a severe winter. Although this procedure gives plant breeders the best indication of how various genotypes

Received for publication 18 Nov. 1997. Accepted for publication 7 Apr. 1998. Contribution from the Missouri Agricultural Experiment Station, Journal Series no. 12702. This research was supported by the National Turfgrass Evaluation Program. The cost of publishing this paper was defrayed in part by the payment of page charges. Under postal regulations, this paper therefore must be hereby marked advertisement solely to indicate this fact.

${ }^{1}$ Professor. To whom reprint requests should be addressed.

${ }^{2}$ Research Associate.

${ }^{3}$ Associate Professor. respond to adverse winter conditions, the method is slow because conditions for separating genotypes usually occur only once or twice

Several methods have been used to accelerate screening of cool- and warm-season grasses for low-temperature tolerance. Gusta et al. (1980) measured electrolyte leakage (EL) following low temperature exposure of several cool-season grasses. Their results suggested that the EL procedure would be a simple and quick method for evaluating field-acclimated cultivars. Other researchers have used the EL method to predict low temperature tolerance of cool-season grasses following acclimation in controlled environment chambers (Rajashekar et al., 1983). Anderson et al. (1988) used a procedure similar to that of Rajashekar et al. (1983) for testing warmseason grasses. They reported that the EL procedure was relatively labor intensive to conduct and that evaluation of results was difficult. Other researchers have observed new growth after controlled environment freezing as an indication of low temperature tolerance (Fry et al., 1993). This procedure is slower than the electrolyte leakage method and may follow natural acclimatization in the field, in a greenhouse, or in a controlled environment chamber.

The objective of this study was to determine if separation of zoysiagrass genotypes based on low-temperature tolerance could be accelerated by measuring the responses of rhizomes subjected to selected low temperatures in controlled environment freezing chambers. This approach may be useful for eliminating less hardy genotypes in the early years of field testing. in a decade in the Midwest.
'Meyer', 'Belair', 'Sunburst', 'El Toro', 'Korean Common', 'Crowne', 'Palisades', TGSW10 (all Z. japonica), 'Emerald' (Z. japonica $\mathrm{X}$ Z. tenuifolia), and 'Cavalier' (Z. matrella) were evaluated from the 1991 Natl. Turfgrass Evaluation Program zoysiagrass trials. Zoysiagrass plots were established in June 1991 in a Menfro silt loam (fine-silty, mixed, Typic Hapludalf soil) in $3 \times 3-\mathrm{m}$ plots at the Univ. of Missouri Horticulture Research Center, New Franklin. Entries were replicated three times in a randomized complete block design. All entries were fully established by Sept. 1992. A complete fertilizer $(13 \mathrm{~N}-6 \mathrm{P}-11 \mathrm{~K})$ was applied to turf in June and July each year using $\mathrm{N}$ at 48 $\mathrm{kg} \cdot \mathrm{ha}^{-1}$. Zoysiagrass was mowed at $25 \mathrm{~mm}$ twice weekly with a reel mower. Broadleaf weeds were controlled as needed with applications of dimethylamine salts of 2,4-D (2,4dichlorophenoxyacetic acid) at $1.36 \mathrm{~kg} \cdot \mathrm{ha}^{-1}+$ mecoprop [ $( \pm)-2$-(chloro-2-methylphenoxy) propanoic acid] at $0.60 \mathrm{~kg} \cdot \mathrm{ha}^{-1}+$ dicamba $(3,6-$ dichloro-o-anisic acid) at $0.11 \mathrm{~kg} \cdot \mathrm{ha}^{-1}$. Turf was watered as needed to prevent drought stress.

During the last week of January and the first week of Mar. 1993 and 1994, five cores (100 mm diameter $\times 125 \mathrm{~mm}$ deep) were removed from each plot with a putting green cup cutter. The soil portion of each core was separated with a knife from the green verdure and mat, which consisted of a densely intertwined network of rhizomes, roots, decaying plant tissues, and interspersed soil. Rhizomes were removed from the upper $12 \mathrm{~mm}$ soil portion of each core and washed with cold water to remove adhering soil particles. Rhizomes $\approx 2 \mathrm{~mm}$ in diameter with a minimum of four nodes were selected randomly and trimmed to $75 \mathrm{~mm}$ length. From this group of rhizomes, five were randomly selected from each cultivar and in each of the three replications for the freezing test. A 0.01-mm-diameter (30 gauge) copper-constantan thermocouple was placed in contact with a randomly selected rhizome among the five per cultivar and replication to monitor tissue temperature. The five rhizomes and thermocouple were first wrapped in moist cheesecloth, then in aluminum foil before freezing.

Samples were placed in a programmable freezer (Tenney Engineering, Union, N.J.), held at $-2{ }^{\circ} \mathrm{C}$ for $2 \mathrm{~h}$, then cooled at $2{ }^{\circ} \mathrm{C} / \mathrm{h}$. Thermocouple output was read on a digital thermometer. In 1993, five rhizomes per cultivar and replication were removed from the freezer after $2 \mathrm{~h}$ of exposure to $-6,-8$, and -10 ${ }^{\circ} \mathrm{C}$ in January and $-6,-8,-10,-12$, and $-14{ }^{\circ} \mathrm{C}$ in March. The 1994 freezing procedure was the same as that used in 1993 except that test temperatures were $-10,-12,-14,-16$, and -18 ${ }^{\circ} \mathrm{C}$. After low temperature exposure, rhizomes were held in a refrigerator at $2{ }^{\circ} \mathrm{C}$ for $24 \mathrm{~h}$ to thaw slowly. Unfrozen controls were held at 2 ${ }^{\circ} \mathrm{C}$ during the freezing test. After thawing, rhizomes were planted in $25 \times 25$-mm cells in preformed plastic trays filled with vermiculite. The trays were placed in a growth chamber on a $34^{\circ} \mathrm{C}$ day $/ 28^{\circ} \mathrm{C}$ night cycle, $70 \% \mathrm{RH}$, and a $12-\mathrm{h}$ photoperiod at a photosynthetic 
photon flux of $500 \mu \mathrm{mol} \cdot \mathrm{m}^{-2} \cdot \mathrm{s}^{-1}$ at canopy level. Flats were irrigated as needed with distilled water. The number of nodes with regrowth were recorded after 6 weeks in the growth chamber and regrowth from nodes was harvested, dried at $55^{\circ} \mathrm{C}$ for $24 \mathrm{~h}$ and weighed.

Survival ratings $(1=$ dormant or killed to 9 $=100 \%$ green) of zoysiagrass entries in the field were recorded in June 1994 for an esti- mate of recovery after the severe 1993-94 winter. Survival ratings were analyzed as a randomized complete block with ten entries and three replications.

Shoot and mass data were analyzed as a split-plot in time design using the analysis of variance procedure of SAS (SAS Institute, 1989). Since variance associated with dry mass differed after freezing in both years, data for each year were analyzed separately. Shoots were analyzed the same way for consistency. Values for LSD were calculated using the method described by Cochran and Cox (1957).

\section{Results and Discussion}

Shoot numbers of entries differed in both years, with increasing separation of cultivars

Table 1. Total number of shoots produced from five rhizomes of ten zoysiagrass entries following low temperature exposure in Jan. and Mar. 1993.

\begin{tabular}{|c|c|c|c|c|c|c|c|c|c|c|c|}
\hline \multirow{3}{*}{\multicolumn{2}{|c|}{ Entry }} & \multicolumn{10}{|c|}{ Temp $\left({ }^{\circ} \mathrm{C}\right)$} \\
\hline & & \multicolumn{4}{|c|}{ January } & \multicolumn{6}{|c|}{ March } \\
\hline & & $\begin{array}{c}\text { Unfrozen } \\
\text { control }\end{array}$ & -6 & -8 & -10 & $\begin{array}{c}\text { Unfrozen } \\
\text { control }\end{array}$ & -6 & -8 & -10 & -12 & -14 \\
\hline Cavali & & 11 & 8 & 4 & 1 & 10 & 6 & 3 & 1 & 2 & 1 \\
\hline Crown & & 9 & 6 & 6 & 4 & 12 & 6 & 9 & 3 & 1 & 1 \\
\hline El Tor & & 11 & 8 & 6 & 4 & 9 & 6 & 8 & 3 & 3 & 1 \\
\hline Emera & & 11 & 7 & 5 & 3 & 13 & 10 & 7 & 4 & 1 & 0 \\
\hline Palisac & & 13 & 7 & 4 & 3 & 13 & 7 & 6 & 5 & 2 & 1 \\
\hline Belair & & 6 & 8 & 7 & 6 & 7 & 6 & 7 & 6 & 3 & 4 \\
\hline Korear & ommon & 9 & 10 & 7 & 9 & 10 & 8 & 8 & 8 & 7 & 4 \\
\hline Meyer & & 9 & 8 & 7 & 8 & 11 & 7 & 8 & 3 & 5 & 3 \\
\hline Sunbu & & 10 & 7 & 5 & 8 & 11 & 8 & 7 & 7 & 4 & 4 \\
\hline TGS-V & & 9 & 7 & 5 & 6 & 7 & 9 & 10 & 6 & 8 & 4 \\
\hline $\operatorname{LSD}_{0.05}$ & $\begin{array}{l}\text { to comp } \\
\text { to comp } \\
\text { to comp } \\
\text { to comp }\end{array}$ & $\begin{array}{l}\text { ng tempera } \\
\text { s within a t } \\
\text { Entry } \\
\text { ing date (S }\end{array}$ & $\begin{array}{l}\text { Г) wi } \\
\text { ture } \\
\text { try }\end{array}$ & entry & & & & & & & \\
\hline \multicolumn{5}{|c|}{ Source of variation } & \multicolumn{4}{|l|}{$d f$} & \multicolumn{3}{|c|}{ Mean square } \\
\hline \multicolumn{5}{|c|}{ Rep } & \multicolumn{3}{|l|}{2} & & \multicolumn{2}{|c|}{$37.5^{\mathrm{Ns}}$} & \\
\hline \multicolumn{5}{|l|}{ FT } & \multicolumn{3}{|l|}{5} & & \multicolumn{2}{|c|}{$326.9^{* *}$} & \\
\hline \multicolumn{5}{|l|}{ Entry } & \multicolumn{3}{|l|}{9} & & \multicolumn{2}{|c|}{$29.5^{* *}$} & \\
\hline \multicolumn{5}{|c|}{ FT $\times$ Entry } & \multicolumn{3}{|l|}{45} & & \multicolumn{2}{|c|}{$14.6^{* *}$} & \\
\hline \multicolumn{5}{|c|}{ Error a } & \multicolumn{3}{|l|}{118} & & \multicolumn{2}{|c|}{7.2} & \\
\hline \multicolumn{5}{|c|}{$\mathrm{SD}$} & \multicolumn{3}{|l|}{1} & & \multicolumn{2}{|c|}{$8.3^{\mathrm{Ns}}$} & \\
\hline \multicolumn{5}{|c|}{$\mathrm{SD} \times \mathrm{FT}$} & 3 & & & & & & \\
\hline $\mathrm{SD} \times \mathrm{F}$ & & & & & 9 & & & & & & \\
\hline $\mathrm{SD} \times \mathrm{F}$ & $\times$ Entry & & & & 27 & & & & & & \\
\hline Error & & & & & 80 & & & & & & \\
\hline
\end{tabular}

$\overline{\mathrm{Ns},},{ }^{*},{ }^{*}$ Nonsignificant or significant at $P \leq 0.05$ and 0.01 , respectively. Values represent the mean of three replications per entry.

Table 2. Total number of shoots produced from five rhizomes of ten zoysiagrass entries following low temperature exposure in Jan. and Mar. 1994.

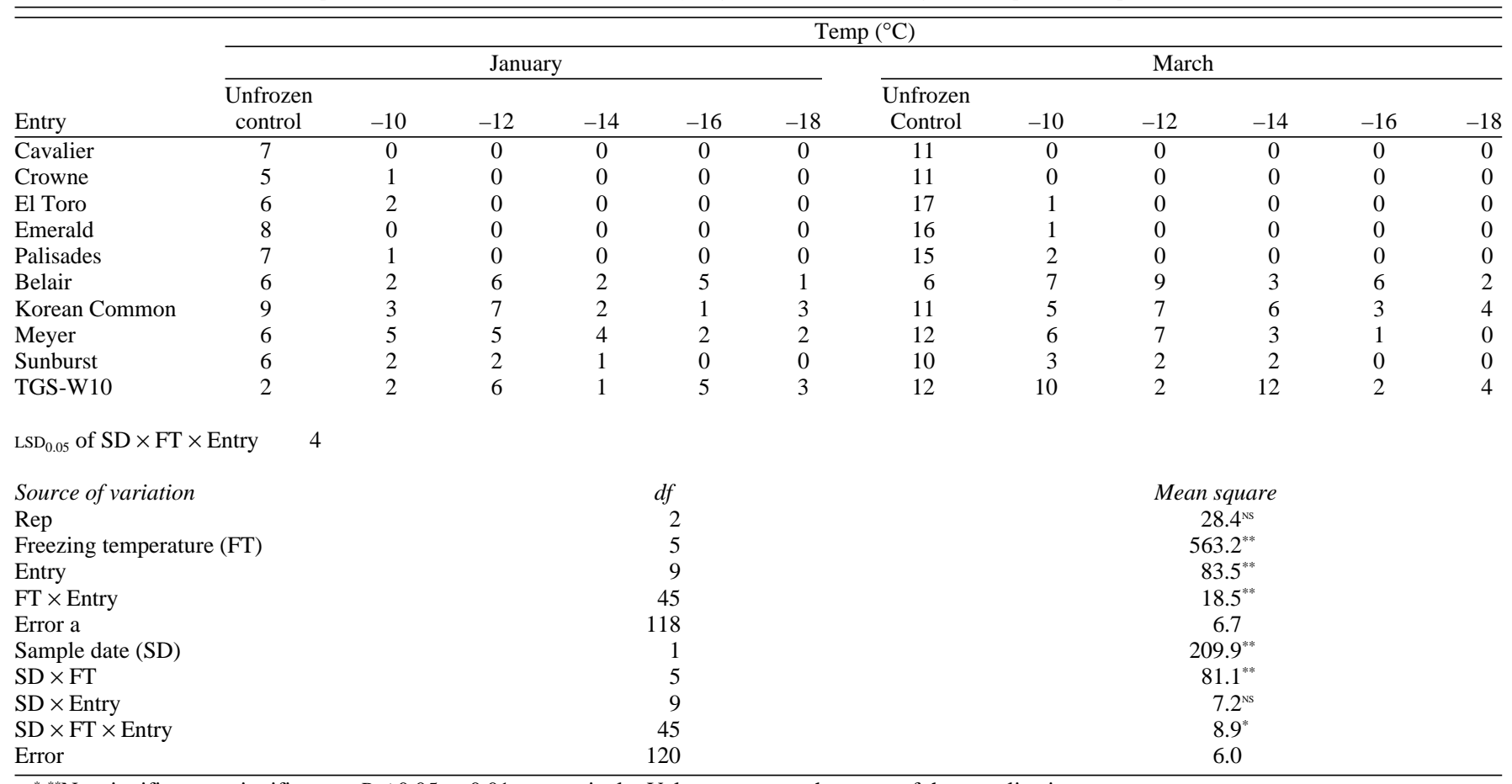

Ns, *, *** Nonsignificant or significant at $P \leq 0.05$ or 0.01 , respectively. Values represent the mean of three replications per entry. 
as test temperatures were lowered (Tables 1 and 2). In Jan. 1993, 'Cavalier', 'Crowne', 'El Toro', 'Emerald', and 'Palisades' produced four or fewer shoots per five rhizomes following exposure to $-10{ }^{\circ} \mathrm{C}$, whereas 'Belair', 'Korean Common', 'Meyer', 'Sunburst', and TGS-W10 produced 6 or 9 shoots (Table 1). In Mar. 1993, 'Cavalier', 'Crowne', 'El Toro',
'Emerald', and 'Palisades' produced one or fewer shoots per five rhizomes following exposure to $-14{ }^{\circ} \mathrm{C}$, whereas 'Belair', 'Korean Common', 'Meyer', 'Sunburst', and TGS-W10 produced 3 or 4 shoots. In Jan. and Mar. 1994, 'Belair', 'Korean Common', 'Meyer', and TGS-W10 survived $-16{ }^{\circ} \mathrm{C}$, but all other cultivars were killed at this temperature (Table 2).
Shoot dry mass (Tables 3 and 4) was not correlated with shoot number $(r=0.24)$. Dry mass might be used to measure the response of single cultivars to multiple temperature freezing tests, but genetic influence on leaf structure precludes comparison among cultivars. For example, in Jan. 1993, robust 'Korean Common' regrowth after exposure to $-6{ }^{\circ} \mathrm{C}$

Table 3. Dry mass of shoot growth from five rhizomes of ten zoysiagrass entries following low temperature exposure in Jan. and Mar. 1993.

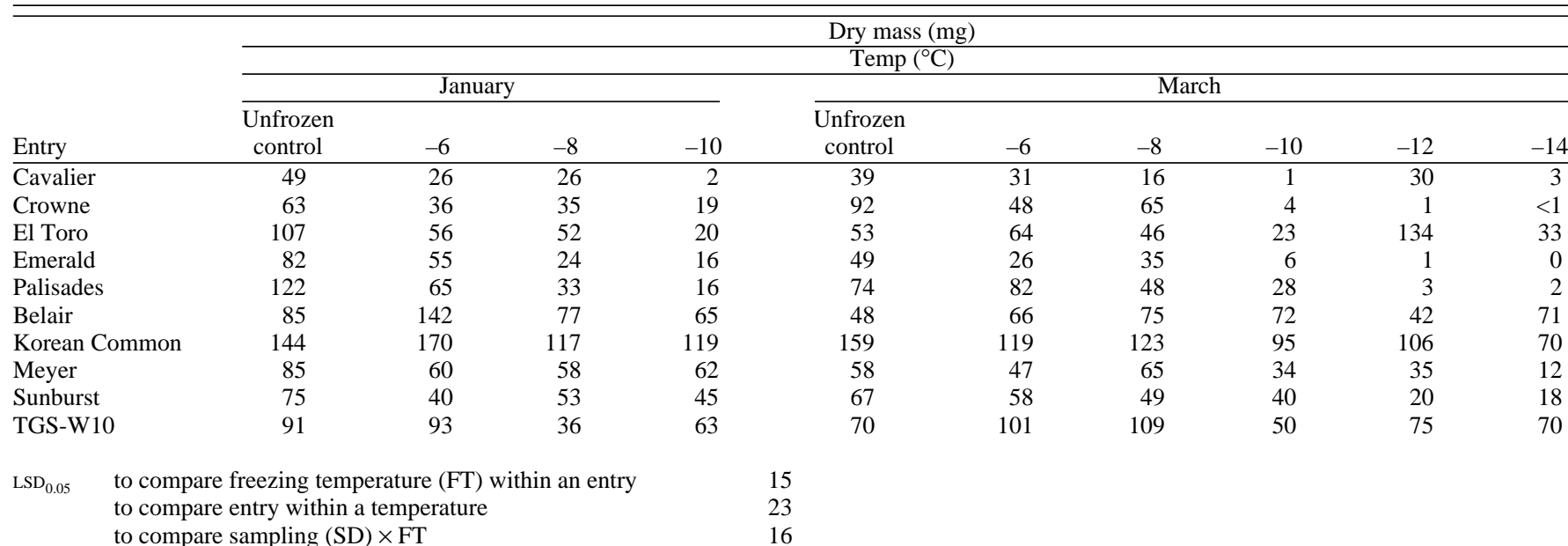

Source of variation

Rep

FT

Entry

FT $\times$ Entry

Error a

SD

$\mathrm{SD} \times \mathrm{FT}$

SD $\times$ Entry

$\mathrm{SD} \times \mathrm{FT} \times$ Entry

Error

$\begin{array}{rc}d f & \text { Mean square } \\ 2 & 5107^{\text {Ns }} \\ 5 & 16932^{* *} \\ 9 & 23750^{* *} \\ 45 & 1556^{\text {Ns }} \\ 118 & 1943 \\ 1 & 2156^{\text {Ns }} \\ 3 & 2654^{*} \\ 9 & 934^{\text {Ns }} \\ 27 & 923^{\text {Ns }} \\ 80 & 963\end{array}$

Ns, *,**Nonsignificant or significant at $P \leq 0.05$ or 0.01 , respectively. Values represent the mean of three replications per entry.

\begin{tabular}{|c|c|c|c|c|c|c|c|c|c|c|c|c|}
\hline \multirow[b]{4}{*}{ Entry } & \multicolumn{12}{|c|}{ Dry mass (mg) } \\
\hline & \multicolumn{12}{|c|}{ Temp $\left({ }^{\circ} \mathrm{C}\right)$} \\
\hline & \multicolumn{6}{|c|}{ January } & \multicolumn{6}{|c|}{ March } \\
\hline & $\begin{array}{c}\text { Unfrozen } \\
\text { control }\end{array}$ & -10 & -12 & -14 & -16 & -18 & $\begin{array}{c}\text { Unfrozen } \\
\text { Control }\end{array}$ & -10 & -12 & -14 & -16 & -18 \\
\hline Cavalier & 45 & 0 & 0 & 0 & 0 & 0 & --- & 0 & 0 & 0 & 0 & 0 \\
\hline Crowne & 64 & 32 & 0 & 2 & 0 & 0 & --- & 0 & 0 & 0 & 0 & 0 \\
\hline El Toro & 109 & 35 & 0 & 0 & 0 & 0 & --- & 3 & 0 & 0 & 0 & 0 \\
\hline Belair & 39 & 41 & 83 & 40 & 42 & 8 & --- & 55 & 52 & 18 & 37 & 10 \\
\hline Korean Common & 107 & 43 & 80 & 72 & 48 & 39 & --- & 47 & 91 & 45 & 22 & 35 \\
\hline Meyer & 71 & 59 & 54 & 25 & 18 & 8 & --- & 12 & 37 & 16 & 6 & 0 \\
\hline Sunburst & 43 & 46 & 21 & 12 & 0 & 0 & -.- & 13 & 6 & 3 & 0 & 0 \\
\hline TGS-W10 & 70 & 30 & 66 & 18 & 61 & 41 & --- & 70 & 13 & 44 & 21 & 18 \\
\hline $\mathrm{LSD}_{0.05}$ of $\mathrm{SD} \times \mathrm{FT} \times$ Entry & & & & & & & & & & & & \\
\hline FT $\times$ Entry & & & & 45 & & & & 11 & & & & \\
\hline Error a & & & & 118 & & & & & & & & \\
\hline Sample date (SD) & & & & 1 & & & & 282 & & & & \\
\hline $\mathrm{SD} \times \mathrm{FT}$ & & & & 5 & & & & & & & & \\
\hline SD $\times$ Entry & & & & 9 & & & & & & & & \\
\hline $\mathrm{SD} \times \mathrm{FT} \times$ Entry & & & & 45 & & & & & & & & \\
\hline Error & & & & 120 & & & & & & & & \\
\hline
\end{tabular}

$\overline{\mathrm{ss}, *, * *}$ Nonsignificant or significant at $P \leq 0.01$, respectively. Values represent the mean of three replications per entry. 
Table 5. Average field survival ratings in June 1994 of 10 NTEP zoysiagrass entries.

\begin{tabular}{lc}
\hline \hline Entry & Survival rating \\
\hline Cavalier & 2.0 \\
Crowne & 3.0 \\
El Toro & 2.3 \\
Emerald & 3.0 \\
Palisades & 2.7 \\
Belair & 8.0 \\
Korean Common & 8.7 \\
Meyer & 6.7 \\
Sunburst & 6.7 \\
TGS-W10 & 8.7 \\
LSD $_{0.05}$ & 1.2
\end{tabular}

${ }^{\mathrm{z} Z o y s i a g r a s s}$ survival rating $=1$ (shoots dormant or dead) to 9 (shoots $100 \%$ green). Values represent the mean of three replications per entry.

freezing weighed more than six times that of the fine textured 'Cavalier' (Table 2), even though 'Korean Common' produced only two more shoots per five rhizomes than did 'Cavalier' (Table 1)

'Belair', 'Korean Common', 'Meyer', 'Sunburst', and TGS-W10 were earliest to recover from winter injury in the field in 1994, with June survival ratings of 6.7 to 8.7 (Table 5). These entries also had the best lowtemperature tolerance, ranging from -14 to $-18{ }^{\circ} \mathrm{C}$ in Jan. and Mar. 1994 (Table 2). In comparison, 'Cavalier', 'Crowne', 'El Toro', 'Emerald', and 'Palisades' showed much slower recovery, with ratings of 2.0 to 3.0 . None of these entries survived freezing test temperatures lower than $-10{ }^{\circ} \mathrm{C}$ (Table 2).

Low temperature injury in the field was severe in some cultivars in 1994 (Table 5) compared with minor injury in 1993 (data not shown). This result may have been associated with differences in January temperatures. For example, in 1994, minimum January air temperatures ranged from -15 to $-22^{\circ} \mathrm{C}$ during a 5-d interval with no snow cover during the 30 d preceding the freezing test. In comparison, Jan. 1993 temperatures were never lower than $-13{ }^{\circ} \mathrm{C}$. Recovery (greenup) began in May 1993 but was delayed until June in 1994.

Evaluation of plants for recovery after controlled freezing may take up to 4 weeks. This procedure is relatively slow compared with rapid methods such as EL. However, the EL method may sometimes overestimate or underestimate low temperature tolerance of warm-season grass. Fry et al. (1993) reported that, since centipedegrass does not exhibit a rapid loss of cell contents at the lethal temperature, the EL method may underestimate lethal temperatures. Maier et al. (1994) stated that EL-predicted lethal temperatures for St. Augustinegrass were lower than regrowth data because the EL method overestimated low temperature tolerance of one of three cutltivars. Field acclimation of entries may influence cultivar responses to controlled freezing tests which differed between years in our study. Therefore, for best separation of entries, freezing tests using field- grown material should be conducted in multiple years.

This study shows that controlled freezing tests may be useful for eliminating less winter hardy zoysiagrass entries in the early years of a field study that otherwise may require up to 10 years for maximum separation for winter hardiness (Dunn, 1991). In this study, TGSW10, 'Sunburst', 'Meyer', 'Korean Common', and 'Belair' were the hardiest entries according to controlled freezing tests and field survival in 1994, whereas 'Emerald', 'El Toro', 'Cavalier', 'Crowne', and 'Palisades' were the least hardy entries.

\section{Literature Cited}

Anderson, J.A., M.P. Kenna, and C.M. Taliaferro. 1988. Cold hardiness of Midiron and Tifgreen bermudagrass. HortScience 23:748-750.

Beard, J.B. 1973. Turfgrass: Science and culture. Prentice Hall, Englewood Cliffs, N.J.

Cochran, G.W. and G.M. Cox. 1957. Experimental designs. Wiley, New York.

Dunn, J.H. 1991. Establishing zoysiagrass. Golf Course Mgt. May, p. 38-52.

Fry, J.D., N.S. Lang, R.G.P. Clifton, and F.P. Maier. 1993. Freezing tolerance and carbohydrate content of low-temperature acclimated and nonacclimated centipedegrass. Crop Sci. 33:10511055.

Gusta, L.V., J.D. Butler, C. Rajashekar, and M.J. Burke. 1980. Freezing resistance of perennial turfgrasses. HortScience 15:494-496.

Maier, F.P., N.S. Lang, and J.D. Fry. 1994. Evaluation of an electrolyte leakage technique to predict St. Augustinegrass freezing tolerance. HortScience 29:316-318.

Rajashekar, C.B., D. Tao, and P.H. Li. 1983. Freezing resistance and cold acclimatization in turfgrasses. HortScience 18:91-93.

Rogers, R.A., J.H. Dunn, and C.J. Nelson. 1977. Photosynthesis and cold hardening in zoysia and bermudagrass. Crop Sci. 77:727-732.

SAS Institute. 1989. SAS user's guide: Statistics. version 6 ed. SAS Inst., Cary, N.C. 